\title{
Unmasking Remarriage Practices of Surviving Spouses in the Midst of the HIVIAIDS Pandemic
}

\author{
Maphosa Cosmas \\ Research Associate Professor, University of Fort Hare, South Africa
}

Maphosa Tendai

Nursing Science Student, University of South Africa

\section{Doi:10.5901/mjss.2014.v5n16p601}

\section{Abstract}

As the HIVIAIDS pandemic continues to wreak havoc in Zimbabwean communities, there is a noticeable trend of surviving spouses remarrying following the demise of their partners. This qualitative study, located in the interpretive paradigm, sought to establish remarrying partners' views on causes for remarriages and the extent to which they took precautionary measures to prevent infection and re-infection. A purposive sample of 2 males and 3 females participated in the study. Data were collected through phenomenological interviews with participants. Content analysis was used to analyse data. The study established that there were social, cultural and economic reasons that lead to remarriages of HIV positive surviving spouses. Participants did not disclose their status to their new partners and precautionary measures were not taking as some couples had children out of the new marriages. The study concludes that HIVIAIDS chances for infections were enhanced and promoted in remarriages and recommends that community programmes on HIVIAIDS awareness should be put in place to educate people on ways of HIVIAIDS transmission and ways to curb the rise of new infections.

Keywords: HIVIAIDS, remarriage, surviving spouses, Zimbabwe

\section{Introduction}

The issue of HIVIAIDS prevalence continues to be a main cause for concern threatening to wipe out societies in Zimbabwe and in the world, in general. Coupled with HIVIAIDS related illnesses are numerous HIVIAIDS related deaths experienced daily. When a partner succumbs to an HIVIAIDS illness, the surviving spouse is left alone and life has to continue. It has been observed that surviving spouses often remarry and live normal lives. In a study on widows and widowers, Ntozi (1997:133) found that in Uganda many widowers who were HIV positive and knew their status went on to remarry following the deaths of their spouses and this resulted in 'the infection of new sexual partners in ways that were unfair and outrageous'.

Mukiza-Gapere and Ntozi (1995) also observe that widows and widowers whose spouses died of AIDS often exhibited reckless behaviour by attracting new sexual partners and entering in new marriages. Mukiza-Gapere and Ntozi (1995) reveal that some of the widows and widowers never revealed their positive sero-status to their new partners and entered into new sexual relationships because they did not want to die alone. Such a motivation for remarriage has a criminal intention. Deliberate infection of a partner is not only unethical but criminal as well. De Walque and Kline (2009) also observe that formerly married individuals are at significantly higher risk for HIV infection through remarriage or involvement in other sexual activities which maybe out of marriage.

In a study on the role of widows in heterosexual transmission of HIV in Zimbabwe, Lopman et al (2009) found that owing to the need to engage in sexual activities following deaths of spouses, widows play a key role in the transmission of HIV. In some instances it will be out of ignorance and a genuine desire to lead a normal sexual life yet in some cases it will be wilful transmission of the virus to unsuspecting partners. It is, therefore, clear that in as much as widows and widowers seek to live normal sexual lives there is always a danger of the possibility of transmission of HIV between couples.

\subsection{HIV/AIDS prevalence in Zimbabwe}

Duri, Stray-Pedersen and Muller (2013) cite Zimbabwe National Statistics Agency (ZIMSTAT) and ICF International 
(2012) data which shows that in the 2010 - 2012 period HIV prevalence was 18\% and 12\% for women and men respectively. In terms of the comparison of prevalence in different areas Duri, Stray-Pedersen and Muller (2013:18) state that:

The epidemic at country level is widely heterogeneous in nature with HIV prevalence in small towns, farming estates and mines located in rural areas (22\%) exceeding that in major cities (14.5\%).

Prevalence of HIV among men and women and in different areas is quite high. The higher HIV prevalence in small towns, farming estates and mines located in rural areas could be attributed to ignorance and lifestyles that promote the spread of HIV. Ministry of Health and Child Welfare and National AIDS Council (2004) states that in 2003 HIV prevalence was $28 \%$ in urban areas and $21 \%$ in rural areas. So despite access to information on preventive measures, urban areas had higher HIV prevalence than rural areas.

Ministry of Health and Child Welfare and National AIDS Council (2004) states that as at 2004, 24.6\% of the whole adult population aged between 15 and 49 was infected by HIV. This shows that the issue of HIVIAIDS is a serious one in Zimbabwe. As the Ministry of Health and Child Welfare and National AIDS Council (2004: 6) reports, the majority of the infected people are not even aware of their HIV status by stating that:

Most HIV positive people do not know they are infected and do not show symptoms. However, they are capable of unknowingly transmitting the virus to others.

Unawareness of one's HIV status could be quite problematic in instances where one's partner dies of an HIV illness and one goes on to remarry. Chances of unknowingly infecting the new partner are very high.

The UNAIDS/WHO (2008) further shows that over 1200000 people were living with HIV in 2007 and this shows that there is a serious problem of HIV prevalence in Zimbabwe. The UNAIDS/WHO (2008) further estimates that 1500 000 children and adults died of AIDS in 2007 alone. This further paints a bad picture on the devastating effects of HIVIAIDS.

\subsection{Reasons for remarriage}

Mutangadura (2000) contends that life after the death of a spouse due to HIVIAIDS often changes for the worse especially in cases where the late spouse was the breadwinner. On widowhood, Ntozi (1997:125) states that:

... it is characterised by grief, bereavement, rituals, forced marriages, harassment, rejection, loneliness, poverty and relative mortality.

It is clear from the above observation that there are a plethora of challenges faced by widows and widowers following the deaths of spouses.

There are numerous reasons why a partner who dies from AIDS will decide to remarry. The United Nations Department of Economic and Social Affairs (2004:44) states that:

Remarriage is potentially another way of coping with economic as well as emotional and social losses resulting from death of a spouse.

It is clear that following the death of a male partner due to AIDS, the surviving spouse experiences coping challenges and remarriage becomes a move meant to address the issue of coping.

The issue of inheritance is also a cause for remarriage. In societies that are still respecting their traditional practices, a widow is expected to be inherited by one of her late husband's brothers. This is more pronounced if the widow will still be of a reproductive age. The inherited is mandated to ensure that family life is propagated hence the need to bear more children with the late brother's wife. Mabunda et al (2007) observes that widow inheritance is prevalent in South-western Uganda and this is exacerbated by low education levels and greed for the late relative's wealth. Mabunda et al (2007) further note that as long as the sexual component is present in wife inheritance it will be difficult to eradicate HIV infection in couples. Mathunjwa and Gary (2006) also point out that issues of culture that include inheritance and polygamy are a major threat to effective fight against AIDS. The same view point is shared by Buseh, Glass and McElmurry (2003).

In a study on socio-cultural and gender factors affecting HIVIAIDS prevention in Malawi, Lindgren, Rankin and 
Rankin (2005) found that women had no power to prevent themselves against HIVIAIDS as their husbands dictated to them what should be done in marriage. This is espoused is women's comments that they were just vessels for their husbands (Lindgren, Rankin and Rankin 2005). In the same vein, Browning (2011) states that within marriages in Tanzania, most decisions about sex were made by men, and not women. The same applies to the issue of inheritance where the husband may inherit a late brother's wife with or without his wife's consent. The inherited wife brought into a polygamous relationship could HIV positive and this leads to the infection of a couple that that maybe HIV negative before the inheritance. This will be done under the guise of culture and patriarchy yet the repercussions of such moves are detrimental to people's lives.

Christianity is also a cause of remarriage in couples. Couples in Christian weddings are believed to be separated by death. Therefore, after the death of a spouse the surviving partners feels free to enter into another marriage contract. Browning (2011) further postulates that the Christian value of faithfulness makes women very vulnerable in marriages, as women may remain faithful even if their spouses may not be. At the end women end up victims despite their faithfulness. Therefore Christian groups that promote abstinence and fidelity without a critique of patriarchy do more to spread HIV/AIDS than to prevent it (Browning, 2011).

Gecaga (2007:143) also advances that in the African culture women are expected to get married in order to bear children by stating that:

In traditional African society there was a procreative emphasis in marriage due to the value attached to children. ... A woman's status in society was determined by the children she bore and her entire life was centred on them.

The above view shows the cultural pressures on women to get married and become mothers. The same pressures are exerted on widows to remarry and have more children. Gecaga (2007) further notes that a woman who had no children was despised. In showing the importance of cultural pressures to get married in the African society, Kyalo (2012: 214) posits that:

The obligation to get married is therefore the only means of human survival as far as the views of African peoples are concerned. For that reason it is a religious obligation. It is as old as the human society, through marriage and childbearing, humanity is preserved, propagated and perpetuated.

In this regard, the importance of marriage and child bearing is a strong expectation resulting in pressures for marriage in the traditional Africa society. Taiwo (2010) states that unmarried women suffered from social humiliation, and polygamy was encouraged to ensure that many women could be married and have children.

The issue of having children in marriage could be viewed as a challenge in view of the need to have partners protect against infection of the HIV virus in marriage. Tangwa (2010:56) observes that:

The failure of the condom, for example, to serve as a method of prevention against the deadly HIVIAIDS infection in some parts of Africa to the same extent as elsewhere in the world could be linked directly to this fact, that the high value placed on children and procreation has been transferred to the sexual act as basically an act of fecundation.

Since marriage is meant for procreation, the issue of using protection in marriage becomes highly impossible and unlikely. The challenge could be in remarried people whose spouses succumbed to HIV related illness. Failure to disclose status and use protection results in multiple infections. The use of protection in marriage is very important in instances where one or both partners are HIV positive. Shisana et al (2004: 537) argue that:

The risk of HIV in marriage is directly linked to non-use of condoms. Some studies have found that married people are less likely to use condoms as a preventive measure.

Marriage becomes a fertile ground for the spread of HIV especially when those who seek remarriages would be HIV positive and do not disclose status and take precautions. Shisana et al (2004) found that married people were also at risk of contracting HIV because they were less likely to use protection.

Ayisi (1997) asserts that marriage, in the African sense, conferred status and dignity to an individual. A married woman or man commanded dignity in respect in society compared to an unmarried one.

\subsection{Problems of HIV infection in married couples}

HIV is easily transmitted in married couples because under the guise of marriage couples are entitled to conjugal rights 
often enjoyed without protection. Matovu (2010) observes that most new HIV infections in sub-Saharan Africa occur in married and cohabiting couples who may not be aware that one of them will be HIV positive. This is a sad scenario especially in remarriages one of the partners would have sought remarriage after losing a former partner through HIV related illnesses. In a similar study, Kaiser et al (2011) acknowledge the prevalence of HIV infection among married and cohabitating couples and call for early couple prevention intervention that includes mutual knowledge of HIV status.

Underscoring the problem of HIV infection in married couples, Dunkle et al (2008: 2183) find women to be very vulnerable and state that 'a woman's greatest risk of contracting HIV lies within a marital status.' Due to social and cultural pressures, a woman cannot demand her husband to take an HIV test. This becomes a problem in widowers who remarry when they are fully aware of their HIV positive status and the married woman has no power to request to know the partner's HIV status. Like a lamb up for slaughter, the woman because of a desire enters into a marital relationship only to be infected with HIV.

Using the Tanzanian experience, Diggos (2007) also observes that women do not have the autonomy in terms of making decisions about HIV testing as they have to seek the husband's permission for that and will be obliged to disclose their result to their husbands. On the contrary, men make their own decisions on testing and may not disclose their results to their wives (Mbwambo, 2001). What is noted in this regard is the issue of the vulnerability of women who may enter into marital relationships with men who know their status and have no power to insist on tests before marriage.

\section{Objective of the Study}

Anglewicz and Reniers (2010) observe that remarriage is seldom studied in sub-Saharan Africa due to data constraints. The present study purposed to establish remarrying partners' views on causes for remarriages and the extent to which they took precautionary measures to prevent infection and re-infection.

\section{Research Methodology}

\subsection{Research paradigm}

By incorporating qualitative methodology into this study, the researchers sought to give priority to the stories of surviving spouses in one rural district in Zimbabwe who had remarried. In retelling and analyzing their stories, the participants attempted to put across their lived experiences. As Merriam (2001: 210) also points out:

The search is not for abstract universals arrived at by statistical generalizations from a sample to a population, but for concrete universals arrived at by studying a specific case in great detail. In attending to the particular [case], concrete universals will be discovered ... This is, in fact, how most people cope with everyday life.

A qualitative study was found suitable for this study whose main aim was to establish views of the participants on remarriages in view of HIV prevalence.

\subsection{Research design}

The study adopted a case study design. Cohen, Manion and Morrison (2007) state that case studies observe effects in real context and provide a unique example of real people in real situations. The present study sought to establish views and sentiments of surviving spouses in marriages by diving pre-eminence to their voice.

\subsection{Research Participants}

A purposive sample of 3 female and 2 males participated in the study. Purposive samples target information-rich sources. Snow-ball sampling also assisted in identifying participants through referral by others. Participants were in marriage following the deaths of their spouses due to AIDS related illness. The researchers used a referral system to target and track surviving spouses who had remarried.

\subsection{Instrumentation}

Phenomenological interviewing was used as the main data collection tool. Lester (1999:1) states that: 
Phenomenological methods are particularly effective at bringing to the fore the experiences and perceptions of individuals from their own perspectives ...

It was the purpose of this study to allow participants to 'tell the stories' regarding the issue of remarriages.

\subsection{Data Analysis}

Content analysis was used to analyse data. Analysis means extracting something systematically. Participants' responses were studied carefully and coded. According to Coffey and Atkinson (1996:32) 'codes are tools to think with.' Emerging patterns were drawn and themes highlighted. In content analysis, care was taken to 'let the text talk' without imposing meanings that were not in text (Graneheim \& Lundman, 2004:113). Verbatim quotations were used extensively in this regard.

\subsection{Trustworthiness}

Elements of credibility, dependability and transferability were considered in ensuring trustworthiness of this qualitative study. To ensure credibility, the most appropriate method for data collection was selected. After analysing data, participants were asked to check for accuracy. Verbatim quotations and use of thick descriptions were used to ensure transferability of findings to other contexts whilst a thorough audit of the research process and findings ensured dependability

\subsection{Ethical Issues}

Verbal consent was sought from participants. Their participation was voluntary and they would not be paid for participating in the study. They were also informed that they would be free to withdraw from the study at any time. The identity of the participants would be protected and all data provided were to be treated in confidence.

\section{Results}

\subsection{Theme 1: Causes for remarriage}

Table 1: Participants views on causes for remarriage

\begin{tabular}{|c|c|c|}
\hline Social & Cultural & Economic \\
\hline $\begin{array}{l}\text { - It is not expected for a woman to be } \\
\text { alone at my age. One needs a } \\
\text { partner. (Participant V) }\end{array}$ & $\begin{array}{l}\text { - I was married to the family hence I had } \\
\text { to be inherited. (Participant V) }\end{array}$ & $\begin{array}{l}\text { My late husband's brother is a successful } \\
\text { farmer and he inherited me so that he could } \\
\text { take care of me and the children. (Participant V) }\end{array}$ \\
\hline $\begin{array}{l}\text { - Even after the passing on of a spouse } \\
\text { one still needs to be loved. } \\
\text { (Participant W) }\end{array}$ & $\begin{array}{l}\text { - I paid lobola in full therefore my in-laws } \\
\text { had to give me my late wife's young } \\
\text { sister as wife following the death of my } \\
\text { first wife. (Participant W) }\end{array}$ & $\begin{array}{l}\text { One should have a wife who does all the } \\
\text { household chores and also work in the garden } \\
\text { to provide for the family. (Participant W) }\end{array}$ \\
\hline $\begin{array}{l}\text { - All my sisters are married (Participant } \\
\text { X) }\end{array}$ & $\begin{array}{l}\text { - I also lost my husband so I had to find } \\
\text { a widower. (Participant X) }\end{array}$ & $\begin{array}{l}\text { Life is difficult if one doesn't have a partner to } \\
\text { help her. } \\
\text { I don't have a job and I don't own any piece of } \\
\text { land. Without a husband life would be difficult } \\
\text { for me. (Participant X) }\end{array}$ \\
\hline $\begin{array}{l}\text { - My sister remarried following the } \\
\text { death of her husband so I am not the } \\
\text { first one to do this. (Participant Y) }\end{array}$ & $\begin{array}{l}\text { - It is expected in our culture to marry. } \\
\text { (Participant } Y \text { ) }\end{array}$ & $\begin{array}{l}\text { Life is difficult for a widow especially these days } \\
\text { of economic hardships. (Participant Y) }\end{array}$ \\
\hline $\begin{array}{l}\text { - I needed more children. (Participant } \\
\text { Z) }\end{array}$ & $\begin{array}{l}\text { - I needed a wife to take care of my } \\
\text { children so I had to marry again. } \\
\text { (Participant Z) }\end{array}$ & $\begin{array}{l}\text { With my new wife, I have someone to help me } \\
\text { in the fields. It was going to be difficult if I was } \\
\text { alone. (Participant Z) }\end{array}$ \\
\hline
\end{tabular}

Table 1 shows that there were social, cultural and economic factors that contributed to participants engaging in remarriages following the deaths of the spouses. The verbatim quotations of the participants captured their views in their own words. 


\subsection{Theme 2: Precautionary measures to prevent HIV infection and re-infection}

Table 2: Participants views on precautionary measures to prevent infection and re-infection.

\begin{tabular}{|l|l|}
\hline Sub-theme on precautionary measures & Verbatim quotations \\
\hline \multirow{5}{*}{ Sero-status Disclosure } & My spouse never told me his HIV status \\
\cline { 2 - 2 } & I did not ask him his status \\
\cline { 2 - 2 } & I never got a chance to know her status \\
\cline { 2 - 2 } & I only knew he was HIV positive when we got tested after our child got seriously ill \\
\hline \multirow{5}{*}{ HIV counselling and testing } & We never got tested when we married \\
\cline { 2 - 2 } & No one talked of tests. We trusted each other \\
\cline { 2 - 2 } & We were tested for HIV two years after marriage \\
\cline { 2 - 2 } & We did not think it was necessary to get tested before we married \\
\hline \multirow{5}{*}{ Use of protective measures } & We don't use condoms in our marriage \\
\cline { 2 - 2 } & My husband does not want to use condoms even though he is HIV positive and I am not. \\
\cline { 2 - 2 } & We are both HIV positive so there is no need to use condoms. \\
\cline { 2 - 2 } & If we use condoms how will we have children? \\
\hline
\end{tabular}

Table 2 shows that there was general non-disclosure of sero-status among remarrying couples, HIV counselling and testing were not prioritised before entering into marriage and there was general problems in the use of protection in marriage. Verbatim quotations from participants revealed these challenges.

\section{Discussion}

It emerged from the study that remarriages had a cultural causation as some felt it was a cultural imperative to marry a late brother's wife in order to take care of children left behind. This finding is consistent with Mabunda et al's (2007) observation that widow inheritance was common in some parts of Africa. In the context of HIVIAIDS prevalence, people were still bound by cultural dictates to inherit widows yet such practices had serious implications on HIV infection and reinfection. The study's finding further support Mathunjwa and Gary's (2006) finding that issues of culture such as inheritance and polygamy are a major threat to effective fight against AIDS.

It also emerged from the study that through cultural imperatives, women would also marry a late sister's husband under the guise of taking care of the late sister's children. Culturally the surviving spouse would have paid bride price in full hence the in-laws were compelled to please their son-in-law by making available a spouse for him from their family. This finding corroborates findings by Gecaga (2007) that in the African culture women were expected to get married in order to bear children. In this view, culture becomes a driver in remarriages despites challenges associated with such marriages in the light of HIVIAIDS prevalence.

The study also established that women were generally economically disadvantaged and remarried following the deaths of the spouses in order to be taken care of. Such a finding confirms assertions by The United Nations Department of Economic and Social Affairs (2004) that the only way for women to cope economically is to get married. Widows who would have depended on the late husband for survival would normally find it tough to take care of themselves and the children. They are then forced into remarriage without considering the risks of such marriages.

It also emerged from the study that HIV counselling and testing was not considered important before couples married and connected to this was failure to disclose one's sero-status to the other partner. This finding is consistent with observation by Ayuo et al (2009) that voluntary HIV counselling and testing is important in the fight against HIVIAIDS. Couple counselling and testing is, therefore, important in ensuring that couples know their status and plan accordingly in their marriage. In a related study, Mlay, Lugina and Becker (2008) also found that HIV counselling and testing was also not prioritises as disclosure of HIV-positive status to an HIV negative spouse could lead to divorce or violence against women. Couple counselling and testing, is therefore, encouraged.

The study further established that couples in remarriages generally tended to shy away from the use of condoms as a precautionary measure against HIV and AIDS. This finding supports Chimbiri (2007) and Tangwa (2010) that use of condoms does not really work in marriages where the prime purpose for sex is for procreation. The finding further supports an observation by Shisana et al's (2004) that married people were at risk of contracting HIV because they were less likely to use protection. 


\section{Conclusions}

The researchers conclude that the issue of remarriages following the death of spouses place surviving spouses and their new partners at the risk of HIV infection and reinfection. In the light of the HIV/Aids pandemic, remarriages become one of the key drivers to increase in HIVIAIDS prevalence given the fact that there is general non-disclosure of sero-status before marriage and general reluctance to use condoms in marriage.

\section{Recommendations}

In the light of findings of this present study, the following recommendations are made;

- Community programmes should be enhanced to teach community members about HIVIAIDS transmission modes and dangers in order to curb the rise of new infections and reinfections.

- Couples should be encouraged to undergo HIV counselling and testing before getting married so as to get an awareness of their HIV status and measures they can employ in marriages to reduce infection and reinfection.

- Communities should reflect on some cultural practices that promote HIV infection such as inheritance practices.

- Women should be empowered economically through community income generation project so that they are not wholly dependent on men as such dependence forces them to enter into marriages without considering the risks involved.

\section{References}

Anglewicz, P., Reniers, G. (2010). Remarriage and Migration in Rural Malawi. Paa2010.princeton.edu/papers/101029. Accessed 19 June 2013.

Ayisi, O.E. (1997). An Introduction to the Study of African Culture. Nairobi: East African Publishers.

Ayuo, P.O., Were, E., Wools-Kaloustian, K., Baliddawa, J., Sidle, J., Fife, K. (2009). Determinants in HIV counselling and testing in couples in North Rift Kenya. East African Medical Journal 86 (2): 83 - 88.

Browning, M.D. (2011).Patriarchy, Christianity, and the African HIVIAIDS Epidemic: Rethinking Christian Marriage in Light of the Experiences of HIV Positive Women in Tanzania. PhD Dissertation: Loyola University Chicago.

Buseh, A.G., Glass, L.K., Mcelmurry, B.J. (2002). Cultural and Gender Issues Related To HIVIAids Prevention In Rural Swaziland: A Focus Group Analysis. Health Care for Women International 23(2):173-84.

Chimbiri, A. (2007). The condom is an 'intruder' in marriage: evidence from rural Malawi. Social Science and Medicine 64 (5): 1102 1115.

Coffey, A., Atkinson, P. (1996). Making Sense of Qualitative Data. Complementary Research Strategies. London: Sage Publications.

Cohen, L., Manion, L., Morrison, K. (2007). Research Methods in Education. New York: Routledge.

De Walque, D., Kline, R. (2009). The Association between Remarriage and HIV Infection: Evidence from National HIV Surveys in Africa. World Bank Policy Research Working Paper Series, VoAvailable at SSRN: http://ssrn.com/abstract=1503812. Accessed 12 February 2013.

Diggos, H.A. (2007). HIV transmission within marriage: findings from Tanzania. Master of Public Health Thesis. Amsterdam: Royal Tropical Institute, Vrije Universiteit Amsterdam.

Dunkle, K.L., Stephenson, R., Karita, E., Chomba, E., Kayitenkore, K., Vwalika, C., Greenberg, L., Allen, S. (2008). New heterosexually transmitted HIV infections in married or cohabitating couples in urban Zambia and Rwanda: an analysis of survey and clinical data. Lancet 371: $2183-2191$.

Duri, K., Stray-Pedersen, B., Muller, F. (2013). HIVIAIDS: The Zimbabwean situation and trends. American Journal of Clinical Medicine Research 1 (1): 15 - 22.

Gecaga, M. (2007). The plight of the African child: reflections on the response of the church. Studies in World Christianity 13 (2): 142 159.

Graneheim, U.H., Lundman, B. (2004). Qualitative content analysis in nursing research: concepts, procedures and measures to achieve trustworthiness. Nurse Education Today 24 (1): 105-112.

Halperin, D.T., Mugurungi, O., Hallet, T.B., Muchini, B., Campbell, B., Magure, T., Benedikt, C., Gregson, S. (2011). A Surprising Prevention Success: Why Did The HIV Epidemic Decline In Zimbabwe? Plos Medicine, 8 (2): E1000414 Doi: 10.1371/Journal.Pmed.1000414. Accessed 10 December 2013.

Kaiser, R., Bunnell, B., Hightower, A., Kim, A.A., Cherutich, P., Oluch, T., Mureithi, P., Mugo, N., Mermin, J. (2011). Factors associated with HIV infection in married or cohabitating couples in Kenya: results from a nationally representative study. PLOS ONE 6 (3). www.plosone.org/article/info: doi/10.1371/journal.pone.001742. Accessed 2 November 2012.

Kyalo, P. (2012). A reflection on the African traditional values of marriage and sexuality. International Journal of Academic Research in Progressive Education and Development 1 (2): 211 - 219. 
Lindgren, T., Rankin, S. H., Rankin, W. W. (2005). Malawi women and HIV: socio-cultural factors and barriers to prevention. Women Health. 41(1):69-86.

Loewenson, R., Whiteside, A. (1997). Social And Economic Issues Of HIV/Aids In Southern Africa. Harare. Southern Africa Aids Information Dissemination Service.

Lopman, B.A., Nyamukapa, C., Hallet, T.B., Mushati, P., Spark-Du Preez, N., Kurwa, F., Wambe, M., Gregson, S. (2009). Role of Widows in the Heterosexual Transmission of HIV in

Manicaland, Zimbabwe, 1998-2003. Sexually Transmitted Infections 85:i41-i48.

Mabumba, E.D., Mugyenyi, P., Batwala, V., Mulogo, E.M., Mirembe, J., Khan, F.A., Liljestrand, J. (2007). Widow Inheritance and HIVIAids in Rural Uganda. Tropical Doctor.37(4):229-231.

Mathunjwa, T.R., Gary, F.A. (2006). Women and HIVIAids In The Kingdom Of Swaziland: Culture And Risks. Journal of National Black Nurses Association 17(2):39-46.

Matovu, J.K. (2010). Preventing HIV transmission in married and cohabiting HIV-discordant couples in sub-Saharan Africa through combination prevention. Current HIV Research 8 (6): 430 - 440.

Mbwambo, J. (2001). HIV and partner violence: implications for HIV voluntary counselling and testing programs. Washington, DC: Horizons Project, Population Council. http://www.popcouncil.org/pdfs/horizons/vct_violencesum.pdf. Accessed 3 October 2013.

Merriam, S.B. (2001). Qualitative research and case study applications in education. San Francisco: Jossey Bass.

Ministry of Health and Child Welfare and National AIDS Council (2004). The HIV and AIDS Epidemic in Zimbabwe: Where Are We Now? Where Are We Going? Harare: Ministry of Health and Child Welfare.

Mlay, R., Lugina, H., Becker, S. (2008). Couple counselling and testing for HIV at antenatal clinics: views from men, women and counsellors. AIDS Care 20 (3): 356 - 360.

Mukiza-Gapere, J., Ntozi, J.P.M. (1995). Impact of AIDS on marriage patterns, customs and practices in Uganda (P201-208). In The Third World AIDS Epidemic Oruboye IO, Caldewell JC, Caldwell P, Jain S Health Transition Review 5 Canberra: Australian National University.

Mutangadura, G. (2000). Household Welfare Impacts of Mortality of Adult Females In Zimbabwe: Implications For Policy And Program Development. Paper Presented At the Aids and Economics Symposium Orgnanised by laen, Durban, South Africa $7-8$ July 2000.

Ntozi, J.P.M. (1997). Widowhood, remarriage and migration during HIVIAIDS epidemic in Uganda. Health Transition Review 7 (3): $125-$ 144.

Shisana, O., Zungu-Dirwayi, N., Simbayi, L.C., Malik, S., Zuma, K. (2004). Marital Status and risk of HIV infection in South Africa. South African Medical Journal 94 (7): 537 -543.

Taiwo, A.O. (2010). Power and womanhood in Africa: an introductory evaluation. The Journal of Pan African Studies 3 (6):229 - 238.

Tangwa, G.B. (2002). ART and African sociocultural practices: worldview, belief and value systems with particular reference to francophone Africa. In Vayena E, Rowe PJ, Griffin PD (eds). Current Practices and Controversies in Assisted Reproduction. Geneva: World Health Organization. (p 55-59).

United Nations Department Of Economic And Social Affairs (2004). The Impact Of Aids. New York: United Nations Publications.

Zimbabwe National Statistics Agency (ZIMSTAT) and ICF International (2012). Zimbabwe Demographic and Health Survey $2010-11$. Calverton, Maryland: ZISTAT and ICF International Inc. 